\title{
Secondary Syphilis in Man: Prozone Effect
}

\author{
Nayrton Kalys Cruz dos Anjos', Daniel Almeida da Costa1, Thiago Sande Miguel'1, \\ Livia Cristina de Melo Pino ${ }^{1}$, Sebastião Célio Horta Coelho Filho ${ }^{1}$, Débora Trindade Martins ${ }^{1}$, \\ Vinicius Sande Miguel², Bruna Sande Miguel², Fernando Antônio Galvão Pereira Jr.', \\ Vinicius Moreira Paladino
}

\author{
${ }^{1}$ Faculdade de Medicina de Valença, Rio de Janeiro, Brazil \\ ${ }^{2}$ Universidade Unigranrio, Rio de Janeiro, Brazil \\ Email: professordanielfmv@gmail.com
}

How to cite this paper: dos Anjos, N.K.C., da Costa, D.A., Miguel, T.S., de Melo Pino, L.C., Filho, S.C.H.C., Martins, D.T., Miguel, V.S., Miguel, B.S., Pereira Jr., F.A.G. and Paladino, V.M. (2018) Secondary Syphilis in Man: Prozone Effect. Journal of Biosciences and Medicines, 6, 1-8.

https://doi.org/10.4236/jbm.2018.62001

Received: October 13, 2017

Accepted: February 4, 2018

Published: February 7, 2018

Copyright $(9) 2018$ by authors and Scientific Research Publishing Inc. This work is licensed under the Creative Commons Attribution International License (CC BY 4.0).

http://creativecommons.org/licenses/by/4.0/

\begin{abstract}
Introduction: Syphilis consists in a systemic infect contagious pathology with a chronic character. The etiological agent consists of an anaerobic spirochete bacterium, Treponema pallidum. Laboratory diagnosis can be made through a direct investigation of the etiologic agent or non-treponemal (VDRL) and treponemal (FTA-Abs) serological tests. False-negative results are rare. Objectives: The present report presents a rare case of a man with a secondary syphilis syndrome who was initially undiagnosed due to the prozone effect, since he presented VDRL in low titers, and was later confirmed with a new diluted serum sample and VDRL and FTA-Abs, which were positive. Conclusion: A close look should be given to patients who, although the clinical condition is compatible, complementary exams may not be, and clinical cases should be carefully evaluated so that the patient is not treated late.
\end{abstract}

\section{Keywords}

Secondary Syphilis, Prozone Effect, Treponema pallidum

\section{Introduction}

Syphilis is a systemic infectious disease with chronic evolution, in which is susceptible to outbreaks of syphilitic disease and to periods of restlessness, latency. The major route of transmission is sexual intercourse, acquired, but it can occur vertically or congenitally, and, in rarer cases, atypical transmission by accident with contaminated material or blood transfusions. When a pregnant woman acquires the infection, there is a potential risk of fetal involvement, which can lead to severe pictures and marked sequelae. During its evolution it develops symptomatic episodes of active disease interspersed with latency periods. Also 
known as LUES, this is easy to diagnose, simple treatment, cheap and with a high cure rate. The etiological agent is an anaerobic spirochete bacterium, Treponema pallidum [1] [2] [3].

This disease can be classified into stages. The recent acquired form is the one that has up to one year of infection, and can be diagnosed as primary, secondary and recent latent. Another form is the late acquired, which summarizes that infection that has another year of evolution, and can be diagnosed as latent late and tertiary. Congenital Syphilis may be recent or late, with mean, can have less or more than two years of evolution, respectively. Infection acquired when untreated, up to $35 \%$ will evolve to cure, $35 \%$ to latent form, and the remainder will progress to the tertiary stage [4] [5] [6]. Congenital syphilis is responsible for high rates of neonatal death, fetal death and miscarriage. Thus, considered a serious public health problem in Brazil and in the world [7] [8] [9].

The disease can affect the organism in a serious and irreversible way, as well as greatly increase the patient's risk of infection with the human immunodeficiency virus (HIV), where its penetration is facilitated by syphilitic lesions. The individual infected with HIV virus presents a more rapid evolution to the acquired immunodeficiency syndrome (AIDS) when there is a concomitant infection with Treponema pallidum [10] [11] [12] [13].

Laboratory diagnosis can be made through the direct etiologic agent investigation in material collected by scraping the lesions or by puncture of lymph nodes. This can be done by dark field microscopy, which is the gold standard for the diagnosis of primary syphilis, or by direct immunofluorescence [14] [15] [16].

Non-treponemal tests (VDRL-Venereal Diseases Research Laboratory) are performed to track infection, but are not as specific and not absolute for this, as they may be positive in other diseases, leading to false positive results, such as In Systemic Lupus Erythematosus, Antiphospholipid Syndrome, Mononucleosis, Malaria, Chagas Disease, Leptospirosis and Tuberculosis. Due to its specificity in congenital syphilis, high sensitivity in adult syphilis, low cost and easy to perform, VDRL is widely used in Brazil, also being a method to evaluate the serological cure [7] [17].

False-negative results are rare, $1 \%-2 \%$, which makes VDRL a test of high sensitivity and low specificity. This reaction may occur in cases of very recent syphilis infections or because of the prozone effect, which represents an excessive immune response in the formation of antibodies resulting from the infection, with no visualization of the antigen and antibody agglutination. Because of this, an erroneous reading of the VDRL values occurs. To avoid this effect, it is important to always dilute the analyzed serum. Non-treponemal tests are quantified by progressive dilutions, so that the higher the dilution, the higher the antibody concentration. The title values may decrease even without treatment, but only negatives after specific therapy or may remain positive after treatment [7] [17] [18]. 
The treponemal tests (FTA-Abs-Fluorescent Treponemal Antibody absorption. MHA-TP-Microhemaglutination Assay for Treponema pallidum. ELISA-Enzyme-Linked Immunosorbent Assay. EQL-Electro chemiluminescence), detect antibodies to Treponema pallidum and thus can establish the diagnosis. These are the first tests that are positive, on average from the first to the second week after infection, and are used to confirm cases of positive VDRL or in cases where it is negative, or in situations where the patient presents characteristic clinical features [19].

\section{Case Report}

J.A.S.N., male, 56 years old, white, married, father of three, treasurer, natural and resident of Valença-RJ. He sought care at the Luiz Gioseffi Jannuzzi School Hospital (in Portuguese-HELGJ) of the Faculty of Medicine of Valença, in May 2017. Patient reports that for two months he started with generalized malaise, prostration, adynamia, weight loss of $3 \mathrm{~kg}$ from the beginning of the condition and diaphoresis at night. As a history of the current disease, he claimed that for the last twenty days he had started with macular exanthema on the trunk and face, which later spread to the upper and lower limbs with digit oppression disappearance (Figures 1-4).

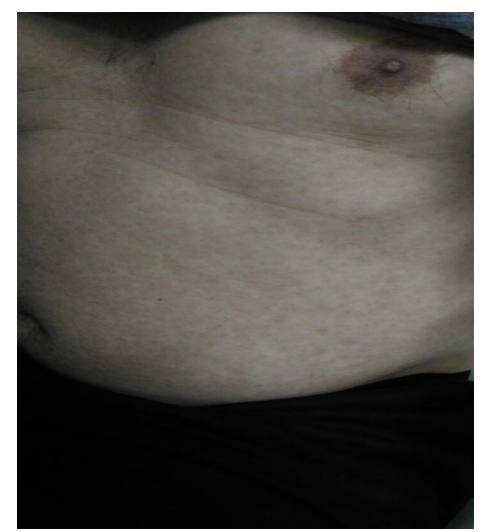

Figure 1. Presence of erythematous-macular rash in the thoracic region and abdomen.

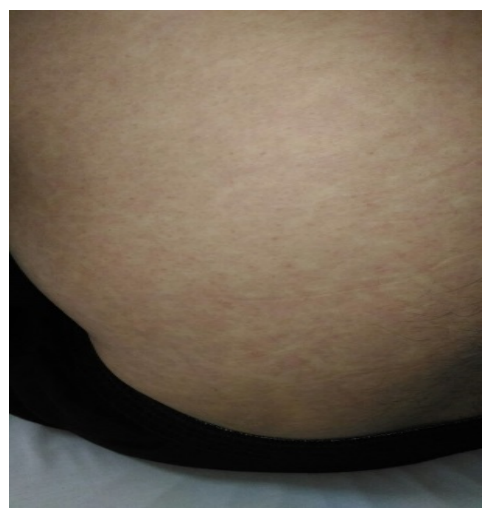

Figure 2. Presence of erythematous macular rash in the thoracic and dorsal regions. 


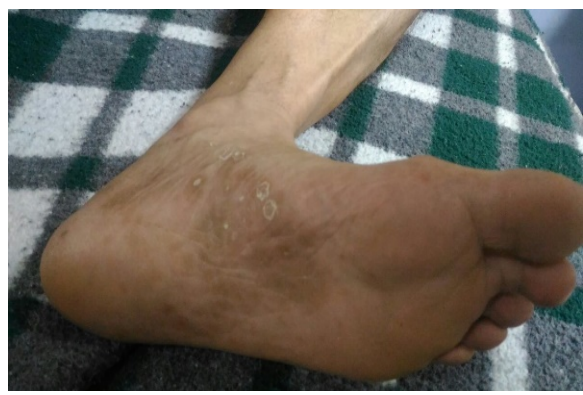

Figure 3. Presence of syphilitic roseola characterized by oval erythematous macules in the plantar region.

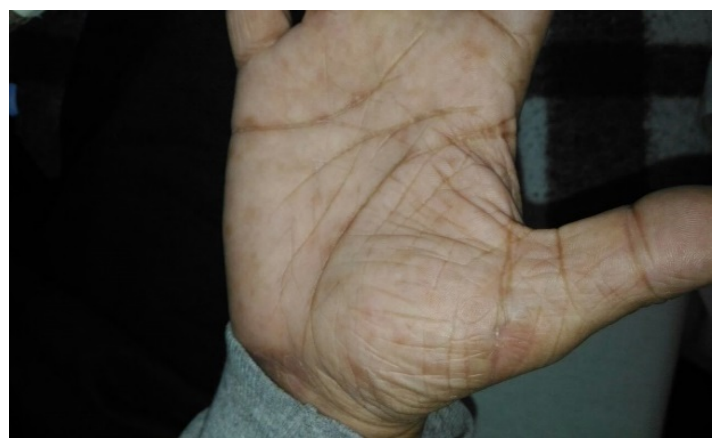

Figure 4. Presence of syphilitic roseola characterized by oval erythematous macules in the palmar region.

During this period, he developed febrile episodes of $38^{\circ} \mathrm{C}$. It denies previous pathologies, chronic use of medications, drug allergies and also hospitalizations or previous surgeries. Family history reveals father died due to neoplasm of cervical region. Alcoholic and smoker (1 year/pack).

After initially discarding the dengue diagnosis, hospital admission was requested for investigation, where the patient reported only night chills. During this period laboratory tests were performed, which are represented in Table 1.

After the tests collection, the suspicion of prozone effect was raised and confirmed after the serum dilution in a new sample with a result of VDRL 1:32 and FTA-Abs positive, so that the pathology propaedeutic was approached after closure of the diagnosis and the patient being cured from its initial condition.

It is worth noting that the patient was duly explained about his pathological condition and was willing to publish this report, signing the Informed Consent Term, which made it possible to publish it.

\section{Discussion}

There is an increase in syphilis incidence, mostly in young men, and especially in those with homo-affective behaviors. One of the reasons for this increase is the change in risk behavior, mainly due to a reduction in the practices of safe sex between them [20]. Thus, syphilis appears to be regaining its importance in the landscape of infectious diseases and is currently one of the main predictors of non-use of condoms. It is known that in recent years, the increase in sexual 
Table 1. Laboratorial Exams.

\begin{tabular}{|c|c|c|c|}
\hline Laboratorial tests & Results & Laboratorial tests & Results \\
\hline Herpes simple $\times$ I e II - IgG & $30.6 \mathrm{U} / \mathrm{ml}$ & Hemoglobina & $11.6 \mathrm{~g} \%$ \\
\hline Herpes simple $\times$ I e II - IgM & NR & Leucograma & $4.000 / \mathrm{mm}^{3}$ \\
\hline Epstein Barr virus - IgG & $322 \mathrm{U} / \mathrm{ml}$ & Creatinina & $0.9 \mathrm{mg} / \mathrm{dL}$ \\
\hline Epstein Barr virus - IgM & NR & Uréia & $20 \mathrm{mg} / \mathrm{dL}$ \\
\hline Toxoplasmose - IgG & $2.6 \mathrm{U} / \mathrm{ml}$ & Calcium & $8.4 \mathrm{mg} / \mathrm{dL}$ \\
\hline Toxoplasmose - IgM & NR & Sodium & $138 \mathrm{mg} / \mathrm{dL}$ \\
\hline Citomegalovirus - IgG & $233.5 \mathrm{U} / \mathrm{ml}$ & Potassium & $4.2 \mathrm{mg} / \mathrm{dL}$ \\
\hline Citomegalovirus - IgM & NR & Total bilirubin & $0.7 \mathrm{mg} / \mathrm{dL}$ \\
\hline TGP/ALT & $38 \mathrm{UI} / \mathrm{L}$ & Direct bilirubin & $0.5 \mathrm{mg} / \mathrm{dL}$ \\
\hline TGO/AST & $49 \mathrm{UI} / \mathrm{L}$ & Indirect bilirubin & $0.2 \mathrm{mg} / \mathrm{dL}$ \\
\hline Total proteins & $6.1 \mathrm{~g} / \mathrm{dL}$ & Gama-Glutamil transferase & $51 \mathrm{U} / \mathrm{L}$ \\
\hline Albumina & $3.0 \mathrm{~g} / \mathrm{dL}$ & Fosfatase Alcalina & $94 \mathrm{U} / \mathrm{L}$ \\
\hline Glubulina & $3.1 \mathrm{~g} / \mathrm{dL}$ & Desidrogenase Láctica & $311 \mathrm{U} / \mathrm{L}$ \\
\hline Relation Albumina/Globulina & $1.0 \mathrm{~g} / \mathrm{dL}$ & Proteína $\mathrm{C}$ reativa & $5 \mathrm{mg} / \mathrm{dL}$ \\
\hline Hematócrito & $35.40 \%$ & VDRL & $1 \mathrm{p} / 4$ \\
\hline Anti-HIV & NR & FTA-Abs & Positive \\
\hline
\end{tabular}

promiscuity of both genders, makes syphilis regain its importance even after so long the discovery of penicillin, which effectively treats the infected individual. In the report there was no previous history of homo-affective habits, but it should be remembered that the unprotected sexual practice transmits the bacterium regardless of gender or age.

Testing should be performed whenever syphilis is suspected at any stage, for all patients with STDs, at risk groups, and in the prenatal routine [21]. Although it is not the most effective method for diagnosis, the VDRL is the examination of choice for screening, possibly due to its low cost and high availability.

The interaction between syphilis and AIDS virus is of great importance in world scenario. Both are transmitted mainly through the sexual route and affect populations with similar characteristics. HIV can be transported by secretions and transferred by genital ulcers [22] [23]. Serological tests for HIV have been requested in the patient in question, since complete screening is essential in individuals infected with any sexually transmitted disease, especially when it is known that an infection is a door to others, since they have the same means of dissemination.

The diagnosis of syphilis is simple, depends on a good anamnesis, with emphasis on sexual history and analysis of the lesion material to identify the treponema and/or serological tests. Darkfield microscopy is the primary method for diagnosing the primary disease stage, whereas serological tests are the methods of choice for diagnosing secondary, latent and tertiary syphilis, but are not suffi- 
cient alone. Non-treponemal tests are useful for screening, whereas treponemal tests are used for diagnostic confirmation [21] [24]. As the present case reports, the patient did not present active ulcer lesions, which made it impossible to search for Treponema pallidum under ark field microscopy. In addition, it had systemic symptoms, which may be present in syphilis, but are not in themselves predictors of this diagnosis. During the hospital stay, he underwent laboratory tests, including VDRL and imaging in search of the symptoms etiology presented by the patient. However, the initial result of the first VDRL test was normal, 1:4, since titers greater than this value were considered positive.

VDRL is subject to false-negative and false-positive results. The high amount of antibodies in the undiluted serum, especially in secondary syphilis, can cause the prozone effect, in order to render the reaction unreactive. However, when performed with previously diluted serum, it may become reagent. This effect can occur in about $1 \%-2 \%$ of cases in the secondary phase, and is not observed in treponemal tests [25]. Antibodies in their exception may reproduce false-negative effect due to their large number in the serum, which may express a false-negative result. As the patient had a clinical history of systemic symptoms such as adynamia, prostration and malaise and physical examination of lesions that transmitted secondary syphilis, the VDRL was requested, which, together with all other laboratory tests and serologies, presented without alterations. To confirm the case, serum dilution and re-analysis of the VDRL, as well as the treponemal FTA-abs test, were requested, which allowed the case treatment.

\section{Conclusions}

As it can be observed, some authors show that Syphilis is reemerging and that it is a pathology that can bring about great irreversible sequels, being thus a great challenge to health, not only in Brazil, but in the world. In addition, it is a disease that has easy diagnosis and effective therapy with great availability. For this reason, it is always important to consider this diagnostic hypothesis against patients with suggestive clinical and laboratory conditions.

It is important that the doctor based on his/her clinical knowledge generates diagnostic hypotheses, in synchrony with laboratory and imaging exams. However, one should not be dependent on tertiary examinations, with consequent rational use of these, because, not all of them are exact, as perceived in the report, since several may not show the true situation of the patient.

\section{References}

[1] Brasil (2015) Ministério da Saúde. Secretaria de Vigilância em Saúde. Departamento de DST, Aids e Hepatites Virais. Boletim Epidemiológico-Sífilis. Ministério da Saúde, Brasília.

[2] Parker, L.A., Deschutes, E.J., Bornay-Llinares, F.J., Hernandez-Aguado, I., Silva, G., Piragine, R.C. and Lumbreras, B. (2012) Clinical and Socioeconomic Determinants of Congenital Syphilis in Posadas, Argentina. International Journal of Infectious Diseases, 16, 256-261. https://doi.org/10.1016/j.ijid.2011.12.005 
[3] Saraceni, V. and Miranda, A. (2012) Relação entre a cobertura da Estratégia Saúde da Família e o diagnóstico de sífilis na gestação e sífilis congênita. Cadernos de Saúde Pública, 28, 490-496. https://doi.org/10.1590/S0102-311X2012000300009

[4] Requena, C.B., Orasmo, C.R., Ocanha, J.P., Barraviera, S.R., Marques, E. and Marques, S.A. (2014) Malignant Syphilis in an Immunocompetent Female Patient. Anais Brasileiros de Dermatologia, 89, 970-972. https://doi.org/10.1590/abd1806-4841.20143155

[5] Velho, P.E.N.F. (2017) Sexually Transmitted Infections and PRO-LIVES: Based on a Clinical Report. Anais Brasileiros de Dermatologia, 92, 279-280. https://doi.org/10.1590/abd1806-4841.20175433

[6] Lumbiganon, P., et al. (2012) The Epidemiology of Syphilis in Pregnancy. International Journal of STD \& AIDS, 13, 486-494. https://doi.org/10.1258/09564620260079653

[7] Dominguez, R.M.S.M., Szwarcwald, C.L., Souza, P.R.B. and Junior, L.M.C. (2014) Prevalence of Syphilis in Pregnancy and Prenatal Syphilis Testing in Brazil: Birth in Brazil Study. Revista de Saúde Pública, 48, 766-774. https://doi.org/10.1590/S0034-8910.2014048005114

[8] Fernandes, F.R.P., Mousquer, G.J., Castro, L.S., Puga, M.A., Tanaka, T.S.O., Rezende, G.R., et al. (2014) HIV Seroprevalence and High-Risk Sexual Behavior among Female Sex Workers in Central Brazil. AIDS Care, 26, 1095-1099. https://doi.org/10.1080/09540121.2014.894609

[9] Chen, X.S., Yin, Y.P., Wang, Q.Q. and Wang, B.X. (2013) Historical Perspective of Syphilis in the Past 60 Years in China: Eliminated, Forgotten, on the Return. Chinese Medical Journal, 126, 2774-2779.

[10] Causer, L.M., Kaldor, J.M., Conway, D.P., Leslie, D.E., Denham, I., Karapanagiotidis, T., Ryan, C., Wand, H., Anderson, D.A., Robertson, P.W., McNulty, A.M., Donovan, B., Fairley, C.K. and Guy, R.J. (2015) An Evaluation of a Novel Dual Treponemal/Nontreponemal Point-of-Care Test for Syphilis as a Tool to Distinguish Active from Past Treated Infection. Clinical Infectious Diseases, 61, 184-191. https://doi.org/10.1093/cid/civ243

[11] Kay, N.S., Peeling, R.W. and Mabey, D.C. (2014) State of the Art Syphilis Diagnostics: Rapid Point-of-Care Tests. Expert Review of Anti-Infective Therapy, 12, 63-74. https://doi.org/10.1586/14787210.2014.860356

[12] Fernandes, F.R.P., Zanini, P.B., Rezende, G.R., Castro, L.S., Bandeira, L.M., Puga, M.A., et al. (2015) Syphilis Infection, Sexual Practices and Bisexual Behavior among Men Who Have Sex with Men and Transgender Women: A Cross-Sectional Study. Sexually Transmitted Infections, 91, 142-149. https://doi.org/10.1136/sextrans-2014-051589

[13] Brown, M.J., Pugsley, R. and Cohen, S.A. (2015) Meeting Sex Partners through the Internet, Risky Sexual Behavior, and HIV Testing among Sexually Transmitted Infections Clinic Patients. Archives of Sexual Behavior, 44, 509-519. https://doi.org/10.1007/s10508-014-0463-3

[14] Schuelter-Trevisol, F., Custodio, G., Silva, A.C.B., Oliveira, M.B., Wolfart, A. and Trevisol, D.J. (2013) HIV, Hepatitis B and C, and Syphilis Prevalence and Coinfection among Sex Workers in Southern Brazil. Revista da Sociedade Brasileira de Medicina Tropical, 46, 493-497. https://doi.org/10.1590/0037-8682-1364-2013

[15] Bowen, V., Su, J., Torrone, E., Kidd, S. and Weinstock, H. (2015) Increase in Incidence of Congenital Syphilis United States, 2012-2014. Morbidity and Mortality Weekly Report, 64, 1241-1245. https://doi.org/10.15585/mmwr.mm6444a3 
[16] Tipple, C. and Taylor, G.P. (2015) Syphilis Testing, Typing, and Treatment Follow-Up: A New Era for an Old Disease. Current Opinion in Infectious Diseases, 28, 53-60. https://doi.org/10.1097/QCO.0000000000000124

[17] Zheng, N., Guo, Y., Padmadas, S., Wang, B. and Wu, Z. (2014) The Increase of Sexually Transmitted Infections Calls for Simultaneous Preventive Intervention for More Effectively Containing HIV Epidemics in China. BJOG, 121, 35-44. https://doi.org/10.1111/1471-0528.12999

[18] Stamm, L.V. (2015) Syphilis: Antibiotic Treatment and Resistance. Epidemiology \& Infection, 143, 1567-1574. https://doi.org/10.1017/S0950268814002830

[19] Gu, W., Yang, Y., Wu, L., Yang, S. and Ng, L.-K. (2013) Comparing the Performance Characteristics of CSF-TRUST and CSF-VDRL for Syphilis: A Cross-Sectional Study. BMJ Open, 3, e002204. https://doi.org/10.1136/bmjopen-2012-002204

[20] Smith, D.K., Herbst, J.H., Zhang, X. and Rose, C.E. (2015) Condom Effectiveness for HIV Prevention by Consistency of Use among Men Who Have Sex with Men in the United States. Journal of Acquired Immune Deficiency Syndromes, 68, 337-344. https://doi.org/10.1097/QAI.0000000000000461

[21] Ministério da Saúde (2016) Manual Técnico para Diagnóstico da Sífilis/Ministério da Saúde, Secretaria de Vigilância em Saúde, Departamento de Vigilância, Prevenção e Controle das Doenças Sexualmente Transmissíveis, Aids e Hepatites Virais. Ministério da Saúde, Brasília.

[22] Miranda, A.E., Figueiredo, N.C., Pinto, V.M., Page, K. and Talhari, S. (2012) Risk Factors for Syphilis in Young Women Attending a Family Health Programme in Vitoria, Brazil. Anais Brasileiros de Dermatologia, 87, 76-83.

https://doi.org/10.1590/S0365-05962012000100009

[23] Shimabukuro, F.H., da Costa, V.M., da Silva, R.C., et al. (2013) Prozone Effects in Microscopic Agglutination Tests for Leptospirosis in the Sera of Mice Infected with the Pathogenic Leptospira interrogans Serovar Canicola. Memórias do Instituto Oswaldo Cruz, 108, 668-670. https://doi.org/10.1590/0074-0276108052013022

[24] Patton, M.E., Su, J.R., Nelson, R. and Weinstock, H. (2014) Primary and Secondary Syphilis-United States, 2005-2013. Morbidity and Mortality Weekly Report, 63, 402-406.

[25] Wang, C., Yang, L.G., Yang, B., Huang, Z.M. and Li, Z.J. (2012) Syphilis and HIV Antibody Test and Related Knowledge and Behavior Survey among Migrant Workers. Chinese Journal of Disease Control and Prevention, 12, 1104-1105. 